\title{
An Overview of the Current Status of Talent Care and Talent Support in Hungary
}

\author{
CSIlla FuszeK ${ }^{1}$
}

$\approx$ After a short historical introduction, the article provides an overview of the current talent support trends in Hungary. It gives an insight into the legislation, guidelines and institutional system associated with the national talent support strategy, and presents the main NGO initiatives present in the early 21st century, in particular the organisations brought to life by the Hungarian Talent Support Council and their effect on current education policy. At the same time, the article seeks to present the strengths and weaknesses of the national talent support strategy and the Hungarian talent support cooperation model.

Keywords: education, talent support strategy, networking, cooperation model 


\section{Pregled stanja o trenutni skrbi in podpori za talentirane na Madžarskem}

Csilla Fuszek

$\curvearrowright$ Po kratkem zgodovinskem pregledu je v prispevku predstavljen pregled smernic na področju podpore talentiranim na Madžarskem. Podrobneje so predstavljeni zakonodaja, smernice in institucionalni sistem, povezan $\mathrm{z}$ nacionalno strategijo podpore talentiranim. Povzeti so glavne nevladne iniciative $v$ začetku 21. stoletja, še posebej organizacij, katerih nastanek je bil podprt v okviru Madžarskega sveta za podporo talentiranim (Hungarian Talent Support Council), ter njihov vpliv na trenutno izobraževalno politiko. Hkrati skuša prispevek predstaviti prednosti in slabosti nacionalnega sistema podpore nadarjenim in madžarski sodelovalni model podpore nadarjenim.

Ključne besede: izobraževanje, strategija podpore nadarjenim, mreženje, sodelovalni model 


\section{Historical antecedents}

In order to understand the current achievements of Hungarian talent support and the relevant national strategy, the National Talent Programme, let us first briefly review its historical achievements and milestones and, in particular, public education traditions dating from the $20^{\text {th }}$ century, as well as recent NGO initiatives.

\section{The beginnings of institutional talent support}

József Martinkós work on the history of the Hungarian Talent Support Society reviews the milestones of Hungarian talent support and shows how institutionalised talent support emerged in Hungary the $19^{\text {th }}$ century. At that time, the Reform Age $^{2}$ intelligentsia defined the importance of talent support in a way similar to the current approach, which is when the idea that Hungary can only occupy the position that is worthy of it in the European cultural arena by appreciating those with exceptional talents - "educated minds" - emerged (Martinkó, 2006).

The achievements of the first decades of the $20^{\text {th }}$ century are mostly associated with certain renowned personalities. In 1918, psychologist Géza Révész $z^{3}$ published what was a unique paper in the international context under the title Topical Problems of Talent in the journal Magyar Pedagógia. The $1^{\text {st }}$ Talent Protection Congress, organised in 1926 under the ministership of Kúnó Klebersberg, ${ }^{4}$ was undoubtedly a landmark event in the history of Hungarian talent support. The 1935-1947 period saw the launch of several pre-war talent support programmes, and this period has, with good reason, been called the golden age of state-supported talent care. This was the time of the first organised efforts to rescue talent, culminating in the National Programme to Save Hungarian Talent in Villages, encompassing 72 general secondary schools. The first ministry decree on public talent support was released in 1941 (Martinkó, 2006).

In 1948, a new era commenced. It was dominated by the idea that the introduction of compulsory schooling and eight-year primary school had made any special programme to support underprivileged pupils redundant. From that time until the end of the 1970s, talent support could only exist in the form of undercurrents (Martinkó, 2006). Nevertheless, some initiatives of international 
relevance also appeared during this period, such as primary schools specialised in music and singing, which were initiated in 1956 to promote talent selection. The later establishment of primary-level art schools was a consequence of this initiative. The scientific students' movement, a real "Hungaricum" that now involves thousands of university graduates annually, also dates from this time. ${ }^{5}$

\section{The 198 os and developments since the system change ${ }^{6}$}

Hungarian talent support, which boasts remarkable traditions in the identification and development of gifted children, gained new momentum from the early 1980 os on. The first milestone was the formation of the Hungarian Talent Support Society, which was initiated in 1989 by 84 enthusiastic psychologists, lawyers, economists, bankers and entrepreneurs in order to provide an extensive social basis for bringing professional expertise and political will together, thus revitalising Hungarian talent support (Hungarian Talent Support Society, 2014).

The system change and the years following it brought major developments in the legislative environment as well. The concept of talent support reappeared in the legislature. Act LXXIX of 1993 on public education declared that "Children and students shall have the right to receive education and teaching in conformity with their abilities an interests, to pursue further studies, in accordance with their abilities and to receive primary art education in order to discover and develop their artistic talents". The Act codified the still existing primarylevel art school system (regular art schools in the afternoon, mainly financed by a normative budget contribution), through which hundreds of thousands of pupils can test their limits annually and unfold their artistic talents.

Government Decree No. 111/1997 on teacher qualification requirements was also exemplary in Europe, as it was the first decree declaring that talent support should be included in mandatory teacher training. This was followed by a series of government decrees regulating the further training of teachers. ${ }^{7}$ In 1999, the "talent and its development" special educational programme was launched. In the wake of the pioneering work of the Debrecen University, this programme is currently accessible at five locations in the country: Eötvös Loránd University, the Western Hungarian University, Szent István University

6 1989-90.

7 Government Decree No. 277/1997 regulated the further training system of teachers; Decree No. 29/1997 MKM of the Minister of Economic Affairs and Communications covered relevant further training in talent development; and Decree No. 41/1999 OM of the Minister of Education introduced a special talent development examination programme. 
and Eszterházy Károly College, with the latter offering an MA programme for would-be talent support specialist teachers. More than a thousand Hungarian teachers have obtained a talent development specialist degree in recent years, which is a substantial number in European terms as well.

As reflected by the relevant decrees, a positive shift has occurred in the legislative environment of talent support in recent decades and, in parallel, both public and civil society initiatives in talent support increased rapidly in the 1990s. Amongst the latter, the National Youth Scientific and Innovation Contest, organised and led by János Pakucs and László Antos, excelled. It was announced by the Hungarian Innovation Society for the first time in 1991 and was modelled on similar EU initiatives. Anyone could apply with an idea targeting the scientific solution to a particular problem, or with a proposition in the field of the natural sciences (biology, physics, chemistry and geography), environmental protection, IT, telecommunications, computer science and technical sciences or mathematics. With the $1^{\text {st }}$ National Youth Innovation Contest, Hungary became the first East Central Europe country to join the EU contest series.

Representing a novel type of initiative, the Association of Researcher Students commenced in 1996 under the leadership of Péter Csermely. This programme offers research opportunities for secondary school students with excellent abilities at the best Hungarian research sites, with the assistance of a mentor network comprising outstanding scientists. In 2004, it won the EU Descartes Prize, and the idea has since been adapted in several countries (Association of Researcher Students, 2014). In 2005, the Association of Researcher Teachers, another unique civil society initiative, was launched as well (Association of Researcher Teachers, 2014).

These recent NGO activities, of which we have only mentioned the most significant, are organically integrated into the traditionally exclusively public system of Hungarian talent support. Besides subject-specific talent support classes in elementary and secondary school, the traditions have been marked by the Academic Competition of Secondary School Students in Hungary (OKTV), which already has a history of several decades, while Hungarian students have also excelled for decades at the international Student Olympics, in which Hungary is in the vanguard in Europe. The competition-centred approach is most typical of traditional Hungarian talent support, as witnessed by the fact that, in a country with a population of around 10 million, there are currently approximately 300 quality competitions for students in public education, with the number of mathematics and natural sciences contests being particularly high.

Traditional talent support in higher education is based on the activity of scientific students' associations, with a history of more than 60 years. Their 
biannual National Conference of Scientific Students' Associations provides an opportunity for the best university and high school students to present their scientific results to an evaluation committee made up of renowned professionals, professors and members of the Academy. The scientific students' movement, which mobilises tens of thousands of people, also plays a major role in talent identification, and it has been provided with public support since its establishment in 1952 (Scientific Students' Associations, 2014).

At the beginning of the present millennium, not only civil society, but also public talent support was renewed. In 2000, the Ministry of Education announced the Arany János Talent Support Programme, which has to date involved more than ten thousand children and is designed to enhance the opportunities for disadvantaged children living in small settlements to continue their education, in order to promote social mobility and reinforce the intelligentsia in rural areas. Realised through the cooperation of 23 general secondary schools and student hostels with considerable talent support traditions, the programme was the first complex national talent support programme associated with many reforms that have altered previous talent support concepts. This secondary school programme introduced the teaching of learning strategies, and its selfknowledge programme provides effective assistance to talented students, helping them to improve their self-assessment. Its student hostel programmes have increased the amount of time students spend in guided learning. The results of the programme have shown that, with adequate assistance, talented students suffering from multiple disadvantages can produce the same results as their peers coming from middleclass or upper middleclass families. The numerous domestic and foreign presentations of the programme have earned it fame and recognition from the leading authorities in the field (Arany János Talent Support Programme, 2014).

The Complex Talent Support Network Programme of the Borsod-AbaújZemplén County, another programme enjoying public (county) support, went live in 2003. Its aims are to gather together, assist and financially support individual initiatives in the county, to deploy a county network of talent identification, and to support and establish the technical and financial conditions for operation. Its activity was transformed from 2010 on, with its gradual merger into the Talent Point network system established by the Genius Programme, of which it was a model example. While in operation, the programme was studied by numerous Hungarian and European professionals, who propagated this best practice outside Europe as well (Kormos, 2014). 


\section{The National Talent Support Council, 2006}

As demonstrated by the aforementioned projects, there were several substantial public and civil society initiatives in the last two decades of the $20^{\text {th }}$ century and in the early $21^{\text {st }}$ century. These initiatives supplemented and reformed the content and structure of the traditional approaches. In 2006, these talent support activities were brought under an umbrella organisation, a network, thanks mainly to the activity of Professor Péter Csermely. The National Talent Support Council (hereinafter, the Council) started its work with 6 member organisations, mainly NGOs, and currently has 44 members, both domestic and cross-border. It currently has more than 100 partner organisations, and this figure continues to rise. The eight years since the formation of the Council have demonstrated that the creation of an umbrella organisation, based on a civil society initiative, was actually a historical feat, another milestone along the way to the typical Hungarian talent strategy of today. An investigation of the goals of the Council reveals that the members had quite definite ideas right from the start regarding talent support in Hungary and across the borders. Let us sum up in broad strokes - without aiming at completeness - the concepts of the Council that have been realised to date:

- One goal was to create an opportunity for Hungarian and cross-border talent support NGOs to reconcile their standpoints, and to promote and shape the further development of the Hungarian talent support system by studying domestic and foreign examples, organising professional fora, acquiring support options, considering new forms and announcing tenders;

- Pursuant to Government Decree No. 1043/2006 (IV. 19.), the Council now offers a permanent and organised forum for dialogue between member organisations and the administration, enabling member organisations to express their demands and communicate their opinions on the talent-support-related plans of the administration, and to exercise social control over the administration's activity in this regard;

- The Council offers member organisations an opportunity to publish information about themselves on their common website (www.tehetsegpont.hu), in publications, at regional information points (Talent Points), at regional fora and in the media.

Not long after its establishment, the Council felt the need to have a legal personality to pursue its operative activities, and hence the Hungarian Association of Talent Support Organisations (MATEHETSZ) was formed from its 
members and registered on 18 October 2006 (Association of Hungarian Talent Support Organisation, 2014).

\section{Formulation of the National Strategy - 2008}

By early 2008, under the management and coordination of Professor Péter Csermely, the members of the Council managed to jointly compile the so-called Genius Integrated Talent Support Programme, serving as a professional basis for the national talent strategy planned for 20 years.

At the $1^{\text {st }}$ National Conference on Hungarian Talent Support, organised in Budapest on 22 February 2008, the Council was already in a position to share the good news that extensive cooperation had been established to identify and nurture talent. Talent support became a national issue, and the National Talent Programme (NTP), prepared on the basis of Genius, was soon ready to be submitted to Parliament, thanks especially to the devoted work of Professor Péter Csermely, who worded the programme and designed the relevant national strategy, and MP Dénes Kormos, who had a decisive role in ensuring that the bill on the 20-year strategy was passed in Parliament in December 2008 with almost no negative votes. ${ }^{8}$ During 2009, Parliament also passed decrees on the institution of the financial bases of the talent programme. ${ }^{9}$

Thus in 2008, with the Parliamentary Decree referred to above, Hungarian talent support reached another milestone, as Parliament raised it to the level of a public programme, motivated by the revelation that the talent support efforts of the profession and civil society could achieve their goals much more effectively with public support, possibly leading to measurable results already in the successes of the next generations.

Initially, the National Talent Fund created pursuant to the Parliamentary Decree had two main sources. The one that excelled - and now actually remains as the sole source - is a $1 \%$ talent support contribution of citizens based on their PIT. It is welcome news that the number of people offering their $1 \%$ to promote this cause has been rising year by year, thus ensuring the realisation of this national strategy.

8 Decree No. 78/2008 (VI. 13.) OGY of the National Assembly on the National Talent Programme; Decree No. 126/2008 (XII. 4.) OGY of the National Assembly on the adoption of the National Talent Programme, the principles of its financing and the guidelines for the establishment and operation of the National Talent Coordination Forum.

9 Government Decree No. 152/2009 (VII. 23.) on the financing of the National Talent Programme; Government Decree No. 1119/2009 (VII. 23.) on the establishment and operation of the National Talent Coordination Forum. 


\section{Donor private individuals (persons)}

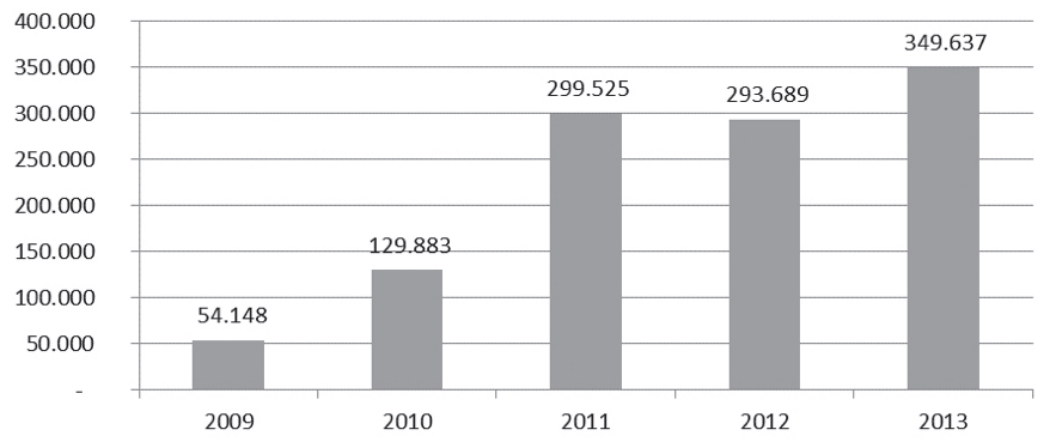

Figure 1. The number of individuals offering $1 \%$ of their income tax has been steadily increasing since 2009

The sums being offered (also derived from other sources, as the case may be) have been increasing consistently, with one major rise in 2011. The HUF $417,330,521$ recorded in 2009 had risen to HUF $1,381,200,878$ by $2013 .{ }^{10}$

The funds (received by the National Talent Fund) earmarked for promoting the accomplishment of the tasks of the National Talent Programme are allocated/utilised on the basis of recommendations by the Talent Coordination Forum. The president of the Forum is the minister responsible for education, and its co-presidents are the President of the National Talent Support Council, an MP delegated by the Education and Science Committee of Parliament, and the President of the Hungarian Academy of Sciences. The minister responsible for education is entitled to make the final decision.

In order to provide for the professional management of the National Talent Programme, the National Talent Support Programme Management Office, which assumes responsibility for the operational management of the Programme, was set up in the Institute for Educational Research and Development, one of the background institutions of the ministry responsible for education.

The functions of the PMU include tasks associated with the operation of the Talent Support Coordination Forum, the development of application plans conforming to the action programme to be submitted to the National Talent Support Coordination Forum, and the wording of tender announcements subsequent to relevant ministerial decisions. The PMU is also responsible for the professional evaluation of the tenders received, their submission for ministerial decision making, and the professional supervision of their implementation. In short, it takes responsibility for the implementation of the National Talent Programme.

10 Information provided by the national Talent Support Management Office. 


\section{Guidelines and action plans of the National Talent Programme:}

The Hungarian National Talent Programme (national strategy) is characterised by a long-term approach, covering a period of 20 years (2008-2028). Its fundamental values are value preservation, diversity, creating opportunities, continuity and interoperability, selection in the active and passive sense, selfdevelopment, efficiency, a gradual approach, responsibility and social commitment, appreciation of talent support staff, sustainability and social support. ${ }^{11}$

The operational objectives are broken down into two-year action plans, and are defined within that context (the third two-year action plan is currently being implemented). Each new action plan overlaps with the previous plan, with minor differences. All of the action plans include a priority development topic, e.g., preservation and enrichment of talent support traditions, ensuring equal opportunities in talent support, enhancement of community-building efforts and social commitment of talented youth, or appreciation of talent staff and organisations (institutions of education and instruction). As a priority objective, the last two plans ${ }^{12}$ have also included familiarisation of the Member States of the European Union, and of other countries, with the achievements of Hungarian talent support. ${ }^{13}$

\section{The Contribution of NGOs to the National Talent Sup- port Programme}

As mentioned above, the National Talent Programme was in fact the result of civil society cooperation under the National Talent Council. MATEHETSZ, the operative body of the Council, has also participated as an applicant to tenders of the National Talent Programme in recent years, and some of its financial units (National Talent Point, European Talent Centre - Budapest) are actually funded through NTP tenders. However, a special situation has arisen on two occasions with MATEHETSZ being the beneficiary of ESA funds received by Hungary. ${ }^{14}$ The first major support was used to implement the revised version of the Genius Integrated Talent Support Programme referred to above, as well as the ongoing Talent Bridges Programme. Both programmes target the fundamental restructuring of Hungarian talent support and are therefore particularly important within the National Talent Programme as a means of ensuring the cooperation of the public and private sectors in talent support.

11 Based on Decree No. 126/2008 (XII. 4.) OGY of the National Assembly.

12 Action Plans for 2011-2012, and for 2013-2014.

13 Based on Nemzeti Jogszabálytár (http://njt.hu/cgi_bin/njt_doc.cgi?docid=162281.246012)

14 2009-2011:TÁMOP (SROP) 3.4.4; 2012-2014: TÁMOP (SROP) 3.4.5. 


\section{Genius and the Talent Bridges Programme}

The core of the restructuring effort under the Genius Programme (2010-13), i.e., the systematic reform of the talent support network, was the deployment of a system based on cooperation and driven by the NGO segment. This process is not yet complete, but its successful grounding is associated with the Genius Programme. The essence of the cooperation model is that every effort to support the talented (e.g., identification, guidance etc.) is channelled to the national system of so-called Talent Points, in order to ensure the best and most diverse support possible to each and every talented person. The system is designed so that the various forms of talent support, both within and beyond the scope of public education, have equal weight within it.

The main components of the establishment of the network were the introduction of the concept of Talent Points, the theoretical grounding of relevant professional standards, and awareness-raising about Talent Points among the talented (as well as their parents and professional supporters) through the internet. The interactive map displayed on the website (http://tehetseg.hu/), which comprises more than 1200 Talent Points from all over the Carpathian Basin, is the outcome of a long process requiring constant professional and graphic renewal.

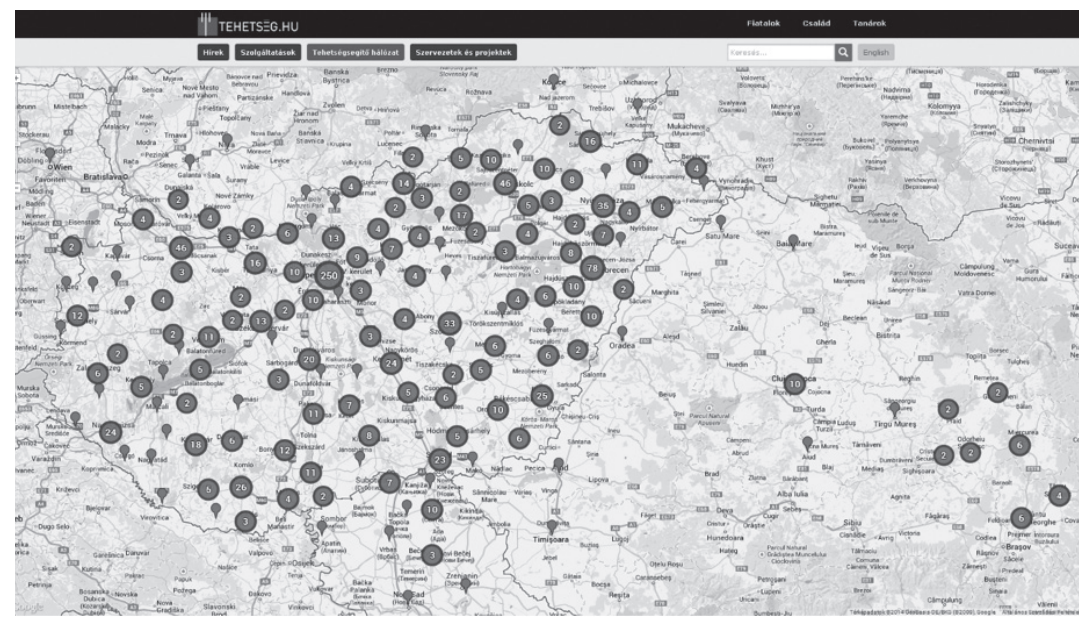

Figure 2. Map of the Hungarian Talent Points - http://tehetseg.hu/ tehetsegpontok/terkep

The website already provides for exceptionally fast communication regarding talent support issues, as witnessed by the hundreds of thousands of 
visitors to its 11,500 pages annually.

The sub-projects of both the Genius and the Talent Bridges programme are mainly based on the structure of the Talent Point cooperation model under construction, and bring together most of the talent-support activities in the country up to 2013, including the most significant activities. Initially, the objectives targeted under the programme mainly concerned the expansion of the professional knowledge and skills of teachers and other professionals working at the Talent Points, with a significant number of short courses (10-30 hours) being designed. More than $10 \%$ of the Hungarian community of teachers have taken part in these courses, and the series of books published under the programme ( 35 volumes to date), which, like the short courses, are based mainly on Hungarian research and best practices, have filled a major gap in Hungary. The Talent Bridges programme (2012-14) focuses on upgrading the existing network structure by providing support to Talent Points, but MATEHETSZ, as the project owner, has also organised many other programmes of direct relevance to talented students or their environments.

Concurrently with the launch of the two programmes, certain tenders under the National Talent Programme have also related to the reinforcement of the talent support network (Talent Bridges Program, 2014).

\section{Civil society structures}

By 2011, the emerging network brought to life the so-called National Talent Point (NTP), dedicated essentially to the development of the website of the network and the storage and maintenance of network data (talent map, database of best practices) within MATEHETSZ, operating with different headcounts depending on the projects. The NTP collects and disseminates the best practices of Hungarian talent support. It is responsible for ensuring the steady and rapid flow of information within the network, and it contributes to communication between the various talent support forms, as well as encouraging connections between domestic and cross-border talent support initiatives by organising publications, talent days and conferences. The National Talent Point is funded from domestic sources by the National Talent Programme.

The National Talent Point has become one of the most significant nodes of the network, but by 2012, so-called talent councils, i.e., self-organised forms with official representation, had also emerged. From the point of view of networking, this may be regarded as one of the most important results of the cooperation model. The councils are built partly on previous, traditionally wellfunctioning networks (such as the Association of Mathematics Teachers), and 
partly on novel groups dedicated to talent support and undergoing dynamic development (the Talent Support Council of Somogy County, the Roma Talent Support Council, the Council to Support Talent with Special Educational Needs, etc.). Many of the regional or national councils have their own publications or websites, which are no longer created out of the components of the existing talent point system. A 2013 survey conducted by Dénes Kormos on the composition of the councils shows how diversified and colourful they are.

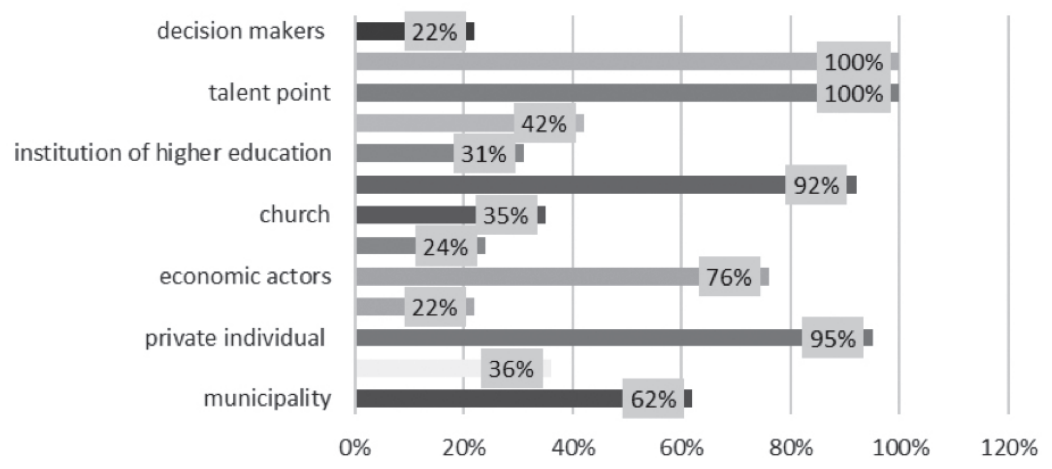

Figure 3. Compositions of the Talent Support Councils in 2013 according to D. Kormos's research

The youngest NGO is the European Talent Centre (EUTC), which is based in Budapest and was formed in mid 2012. It is funded mainly by the Hungarian National Talent Programme, and is dedicated to goals aligned with the guidelines of the NTP. It also focuses on making Hungarian talent programmes visible in foreign languages, preparing best practices for adaptation in the European Union, organising EU Talent Days, initiating EU cooperation and supporting international experience exchange. In short, the EUTC promotes the establishment of a European talent support network, to be modelled, among other things, on the already existing Hungarian talent support model. Cooperation between the EUTC and the European Council for High Ability (ECHA) is exceptionally important in this work (European Talent Centre - Budapest, 2014).

The operation of both the NTP and the EUTC is an excellent example of cooperation between the public and private sectors, as a key point of their operation is close cooperation with MATEHETSZ.

The number of Talent Points has been increasing steadily - at times with extraordinary rapidity - over the past eight years, with 10-12 new activities or 
institutions often being registered on the website weekly. By the end of 2013, this growth had raised questions, as a matter of course, concerning the topological type of the network and the extent to which we can speak of a genuine network of Talent Points with interconnected components. However, to quote Professor Zoltán Néda’s typological research on the initiative of civil society and within the framework of the National Talent Programme, the Talent Points had, by the end of 2013, organised themselves into a real network, thanks to the activities of MATEHETSZ and tenders announced by the NPT. The number of Talent Points without contacts is minimal (5.8\%), and within the network, the National Talent Point, as a key actor in the flow of information in its current status, is of primary importance. Each Talent Point has an average of six network connections; the task ahead is to raise this number, i.e., to establish more and more contact points (Néda, 2014). In this respect, special importance should be assigned to the appropriate tendering system, to maintaining civil society initiatives, to the allocation of the $1 \%$ donated by society to talent-support activities, and to its transfer to talent support organisations.

A crucial and novel feature of the national talent support network is the highly diverse profile of the Talent Points included in it and their special professional content: anything can be a Talent Point, from a chess club to a university department, from a public education institution with a long-standing tradition to teaching units established for only one or two years. The only condition is that their activity is, within the system of the activity concerned, driven by adequate professional standards. Whether one looks at the network as an observer, from the outside, or as a professional, from the inside, its diversity may be difficult to accept and handle, due to the frequent interpretation of standardisation as uniformity, which is actually rather removed from an NGO-based entity, and more typical - perhaps quite rightly - of the public administration point of view.

\section{The emergence of network-based thinking in public talent support}

Decree No. 15/2013 (II. 26.) EMMI of the Minister of Human Resources on the operation of pedagogical expert services created a unique opportunity for the cooperation of the public and the private sectors. As early as 2011, the Public Education Act defined whom the effective legislation regarded a particularly gifted or talented student: ${ }^{15}$ "children/students requiring special treatment, who are highly creative and possess above-average general or special skills, and

15 Act CXC of 2011 on National Public Education. 
strong motivation and commitment may be generated in them towards the task". The Act defines care for particularly gifted or talented students as an obligation of the secondary school, integrated into everyday educational processes. ${ }^{16} \mathrm{On}$ the other hand, Decree No. 15/2013, quoted above, makes talent support a compulsory task of Hungarian pedagogical services, obliging at least one public institution per county and in the capital to care for such students, and instituting the job of talent coordinator in order to achieve this. The national talent coordinator network is currently being established, but its functions ${ }^{17}$ relate expressly to finding the optimum support arrangement for each and every talented child, something that cannot be done without thinking in terms of networks, and a task for which cooperation with the National Talent PMU and the National Talent Point can provide clear-cut assistance.

\section{Summary}

The present article has attempted to provide an overview of the traditions and emerging trends related to Hungarian talent education that have an established statutory framework. Several talent education issues associated with small-scale practice in Hungary, such as acceleration options, have not been discussed in detail. In any country, the unfolding and preservation of talent is, of course, determined by many other circumstances of education policy, culture and infrastructure, from the recognition of teachers and the technical infrastructure of schools, to labour market needs. The National Talent Programme tries to influence these factors in several areas. In some cases, it actually triggers structural changes, but it cannot influence every factor of relevance to talent education. Thus, it can easily happen that interfering techniques coincide, cancelling or weakening each other's effects. Although we have a very high percentage (also by European standards) of teachers with specialist talent education

16 Act CXC of 2011 on National Public Education.

27. $\$(5)$ Making use of the difference between the number of weekly compulsory lessons of the student and the approved weekly time frame for classes, primary schools and secondary schools shall organise sessions for up to three students aimed at developing talents, aiding the inclusion of disadvantaged students and of students diagnosed with adaptive, learning or behavioural disorders, furthermore, activities aimed at the successful preparation of lower grade students. For developing talents and for promoting inclusion, at least one additional hour is ensured for both categories, in excess of the time frame of classes specified in Annex 6.

17 a) in contact with the school/kindergarten psychologists of the institutions of education/ instruction concerned,

b) in contact with the National Talent Point,

c) familiar with/monitors the National Talent Database,

d) familiar with/monitors the tender announcements of the National Talent Programme,

e) in contact with the National Talent Development Centre operating within the Institution for Educational Research and Development. 
qualification - with an ECHA diploma, or who have completed a course on the topic - research-based education is still rather exceptional (TALIS, 2009).

Another strength of Hungarian talent education is the long-term, 20year horizon of the National Talent Programme, which provides a stable and permanent framework for the implementation of many talent support programmes. However, the application-based allocation of funds can generate anomalies and inter-grant conditions, as the central budget system the does not coincide at all with the best task division matching the order of the academic year. This situation is aggravated by the fact that some tasks are not project-like, so it would be reasonable to find arrangements other than tenders for funding them (e.g., National Talent Point).

Yet another strength of Hungarian talent support is that certain signs of network-based thinking are already apparent in both civil society and the public sector. Although every opportunity is provided to intensify such thinking and to establish cooperation, the EU funds that ensure the activity of the Talent Points are also extended in the form of projects, and this is not always compatible with the routine of the public education system. This is very significant, given the fact that two thirds of Talent Points are linked to institutions of public education and, consequently, haphazard funding not only threatens the continuous activity of Talent Points, but may also make public education funds allocated to talent education haphazard as well.

In order to operate the National Talent Programme, it is imperative to have permanent consultations/reconciliation regarding task division of the public sector and NGOs, as the lack of regular dialogue may be conducive to unreasonable arrangements. There are still many unexploited opportunities in cooperation, dialogue and networking.

The key message of the Hungarian National Talent Programme is that the national talent support issue can be made a success through the efficient activity of NGOs, the long-term commitment of the public sector, and the targeted and effective utilisation of EU funds in combination with responsibility sharing.

\section{References}

Arany János Talent Support Programme. (2014). Retrieved from http://www.ajtp.hu Association of Hungarian Talent Support Organization. (2014). Retrieved from http://matehetsz.hu/ Association of Researcher Students. (2014). Retrieved from http://www.kutdiak.hu/ Association of Researcher Teachers. (2014). Retrieved from http://www.kuttanar.hu/ European Talent Centre - Budapest. (2014). Retrieved from http://www.talentcentrebudapest.eu/ 
Fuszek, Cs., Gordon Győri, J., \& Szilágyi, Zs. (2011). A magyar tehetséggondozás eredményei nemzetközi összehasonlitásban in Magyar Tudomány June 2011.

Hungarian Talent Support Society. (2014). Retrieved from http://www.mateh.hu/

Kormos, D. (2013). Kutatás a magyarországi tehetségtanácsokkal kapcsolatban [Research on the Hungarian Talent Councils] (manuscript).

Kormos, D. (2014). Oral Information.

Martinkó, J. (2006). Fejezetek a magyar tehetséggondozás történetéböl [Chapters from the History of the Hungarian Talent Care]. Neveléstörténet, 3-4.

National Talent Program (1). (2014). Retrieved from http://www.nefmi.gov.hu/kozoktatas/nemzetitehetseg-program/nemzeti-tehetsegugyi

National Talent Program (2). (2014). Retrieved from http://www.tehetsegprogram.hu/rolunk

Néda, Z. (2014). On the Structure of Educational Networks. Presentation in Towards a European

Talent Support Network Conference, Budapest 2014

Official Collection of Hungarian Laws and Decrees. Retrieved from http://njt.hu/cgi_bin/njt_doc.

cgi?docid $=162281.246012$

Scientific Students' Associations. (2014). Retrieved from http://www.otdt.hu/hu/

Talent Bridges Program. (2014). Retrieved from www.tehetseg.hu

“Teaching and Learning International Survey" TALIS (2009). Retrieved from http://www.okm.gov. hu/letolt/kozokt/talis_o9o618.pdf

\section{Biographical note}

Csilla FuszeK worked for over 15 years as a teacher in primary, secondary and higher education. Since 2000 she has been focused and become specialized in the field of gifted and talented education. As a civil servant she worked for 7 years as a managing director of nationwide talent development programs aimed to promote equal opportunities to the disadvantaged strata of society. From 2007 - 2011 she was the managing director of the Csányi Foundation. She has been a lecturer at Eötvös Loránd University since 2008 and since 2009 she has been working for the Association of Hungarian Talent Support Organizations on nationwide talent support projects supported by EU funds. Initially she was responsible for establishing international connections and for collecting best practices outside and inside Europe. From 2012 she is the founding director of the Budapest European Talent Centre (www.talentcentrebudapest.eu). 